\title{
TO THE MEMORY OF BELARUSIAN ANTHROPOLOGIST, PROFESSOR LIDIJA IVANOVNA TEGAKO
}

In February 2015 Belarusian anthropology lost its leader. Lidia Ivanovna Tegako, professor, Laureate of the State Prize, passed away in the year of the $50^{\text {th }}$ Anniversary of Belarusian Anthropology, which she had lead and inspired through most of all that period of time.

Lidia Ivanovna Tegako was the organizer of systematic comprehensive anthropological researches on the territory of Belarus through the long time. She also pioneered Ethnic Dermatoglyphics and Odontology in Belarus. The results of those wide researches were announced in her Master's and Doctoral theses, and the numerous publications - books, brochures, manuals, articles. Through the long period of time L.I. Tegako collected palm prints, which make the unique collection, reflecting the regional peculiarities of Dermatoglyphics in the Republic's population.

Lidia Ivanovna made inestimable contribution in scientific training. Six candidates defended theses under her guidance. On the initiative of L.I. Tegako the Dissertation Advisory Committee in anthropology was organized in Belarus for the first time. Lidia Ivanovna paid much of attention to educational activities. She developed the course of lectures on Anthropology for the students of Universities; she became a coauthor of six tutorials. Scientific contacts, effective cooperation and friendly relations with the specialists of allied disciplines flourished due to Lidia Ivanovna's scientific and educational activities. Successful anthropological researches have been carried out on the basis of contracts and common projects with the colleagues from Russia, Serbia, Estonia, Poland.

L.I. Tegako was a member of the European Anthropological Association, she always took an active part in the work of international conferences and symposiums. She organized different international forums on actual questions of anthropology and ecology in our republic.

Lidia Ivanovna started her scientific career in 1966 when she entered postgraduate courses in Anthropology at the Institute of Arts Ethnography and 
Culture. The theme of her $\mathrm{PhD}$ thesis was "Anthropological data to the ethnogenesis of Belarusians (dermatoglyphics and odontology)". Those were the first scientific researches on Dermatoglyphics and Odontology in the Republic. That work, carried out under the scientific supervision of the outstanding anthropologist Valeriy Pavlovitch Alekseev was pioneering in our Republic. The first palm prints of Belarusians she took during her post-graduate courses in 1967. During expeditions Lidia Ivanovna travelled all over the parts of the Republic, and also examined the population of the bordering regions in the neighboring republics - Russians, Latvians, Lithuanians, living in the Grodno region and the Poles, living in the Republic of Lithuania. She also gathered some data on the Tatars, living on the territory of our Republic. Totally 2,500 persons in 8 ethnic groups were examined. Peculiarities in the complex of dermatoglyphic and odontological signs of Belarusians from Western Polesye, which deviated significantly towards the strengthening of Caucasian characteristics, have been elucidated. This peculiar complex of signs was presumably was formed in high antiquity in terms of relative isolation.

The PhD thesis defense in anthropology (03.00.14) took place in 1970 at the specialized thesis examination board in N. Mikluho-Maklay Institute of Ethnology, Academy of Sciences, USSR (Moscow). In 1969 L.I. Tegako was appointed as a junior (from 1973 - a senior, from 1986 - a leading) staff scientist at the sector of Ethnography, Institute of Arts, Ethnography and Folklore Academy of Sciences of the BSSR From this time onwards Lidia Ivanovna was the irreplaceable leader of complex anthropological researches of Belarusian population according to the wide programme, including anthropometry, somatotype, dermatoglyphics, odontology, isoserology, functional signs of cardiovascular system, as well as demographic rates.

Researches were done within the framework of the UNESCO International project "Human and Biosphere". Large quantities of data, which allowed to judge on the anthropological peculiarities of the population, living in Polesie, Poozerie and central parts of Belarus have been obtained during the integrated expeditions. The range of important principles in individual ontogenetic and population changeability of anthropological indices in Belarusians have been defined as the result of consistent and systematic work. The collected database, obtained until 1986 is unique, as it shows the limits of normal population changeability of some functional and morphological signs. With time the research programme had been expanded by including muscle development indices and psychological tests. 
In 1990 Lidia Ivanovna defended the doctoral thesis in the Novosibirsk Medical Institute. The work "Organizational structures of dermatoglyphics and the ways of its population changeability" had been specialized in anatomy (14.00.02). It has to be said that the large-scale statistical analysis of the received data was done by Estonian colleagues from Tartu University, and Lidia Ianovna was always very grateful for that help. Successful doctorate inspired L.I. Tegako for the further development of anthropological researches in Belarus. Lidia Ivanovna became the Head of the Chair of the Department of Anthropology and Ecology, which at that time was organized by the Institute of Arts, Ethnography and Folklore of K. Krapiva.

Research work in physical development and the health status became ever more relevant after the Chernobyl disaster in April 1986, when the population of our Republic was influenced by radiation in a varying degree. Children, teenagers and youth screenings became especially important at that time. In spite of the shortage of staff and economic difficulties in the beginning of the 1990s Lidia Ivanovna managed to organize a comprehensive physical development screening project in 7-17-year-old schoolchildren.

The results of the comparative analysis of growth indicators in children and teen-agers from different regions of Belarus in pre-Chernobyl and postChernobyl periods were included in the monograph "Ecological Changes and Human Biocultural Adaptation".

It is important to say that Lidia Ivanovna had a talent for friendship, maintaining friendly and scientific contacts. The ties of friendship united her with remarkable persons from different countries, outstanding scientists from Russia, Ukraine, Estonia, Latvia, Lithuania, Poland and the Republics of former Czechoslovakia.

From the beginning of 1980s Lidia Ivanovna took part in the international conferences, which were held at the Universities of Tartu and Tallinn. Her papers were published in: "Problems of Physical Anthropology" (Tartu, 1982), "Problems of Modern Anthropology" (Tartu, 1985), "Actual Problems of Anthropology" (Tartu, 1988), "Modern Anthropology to Medicine and National Economy” (Tallinn, 1988).

Scientists from near and far the foreign countries visited international conferences, organized by L.I. Tegako from 1982 to exchange scientific information. Constant guests were leading scientists from Estonia.

The papers of our Estonian colleagues - H. Kaarma (1983, 1993, 2002), L. Heapost $(1983,2006)$, L. Saluste $(1983,1993,2002,2006)$, V. Shvarts (1983, 1991), K. Gross (1983), G. Sarap (1983), G. Veldre (1991, 2002, 2006), Z. Maiste 
(1991, 1993), J. Kasmel (2002), T. Kasmel (2002) were published in the proceedings of the conferences, held by the Department of Anthropology and Ecology.

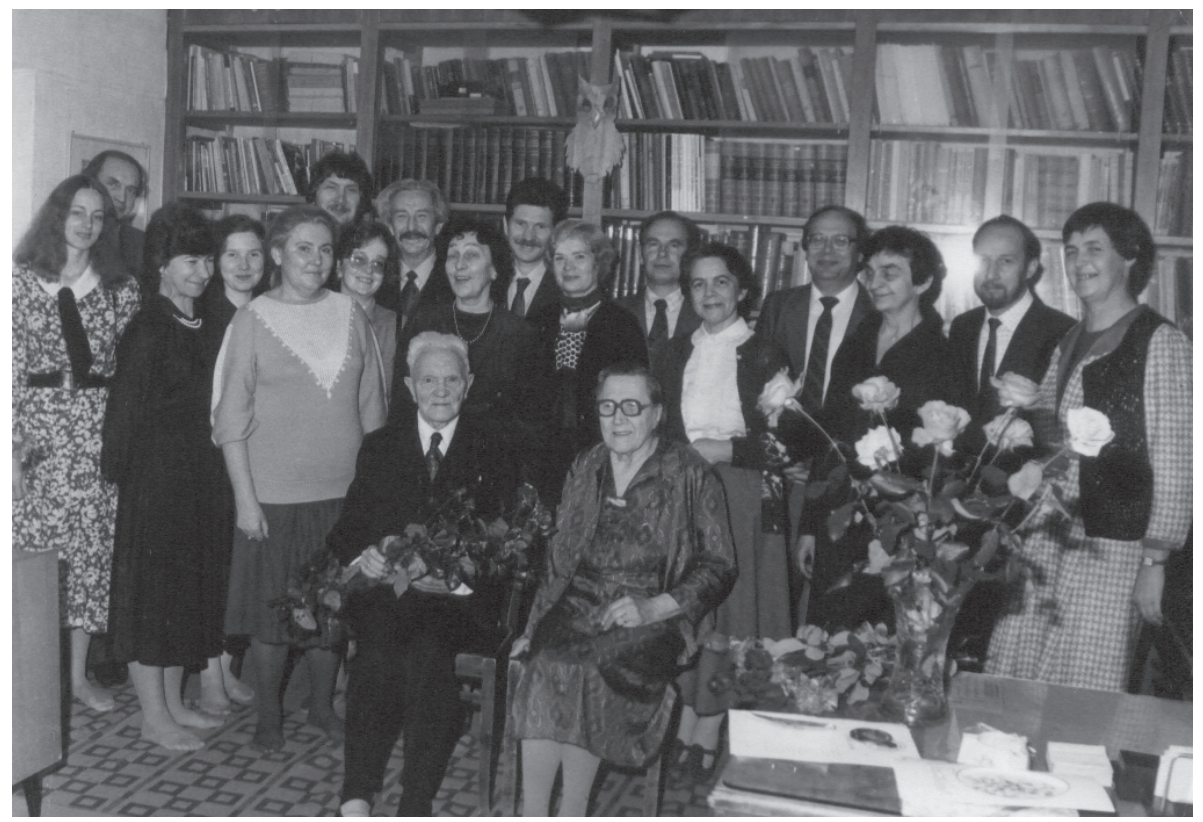

Among Estonian colleagues (prof. J. Aul's $80^{\text {th }}$ birthday celebrations).

The collection of scientific papers "Highlights of Anthropology" was established on the initiative Lidia Ivanovna. It has been included by the Higher Attestation Commission in the range of scientific publications to report the results of dissertations on historical, biological and medical sciences. Recent findings and results in the main problems of Anthropology by Estonian colleagues: H. Kaarma (2008), L. Heapost (2008, 2014), L. Saluste (2008, 2011), G. Veldre (2011), J. Kasmel $(2011,2015)$, T Kasmel $(2011,2015)$ had also been published in these proceedings.

Scientific achievements of Lidia Ivanovna, were highly appreciated by the country. In 1998 the cycle of works "Human and Biocultural Adaptation" by the team of Anthropology and Ecology Department, led by L.I. Tegako, was awarded the State Prize of the Republic of Belarus in the field of humanitarian and social sciences (Decree of the President of the Republic of Belarus №625 as of 28.12.1998). In the same year Lidia Ivanovna became Professor of the Chair. 
One may wonder what may inspire a person to devote her life to such intensive scientific, pedagogical, educational activities, at the price of private time and frequently to the detriment of health. Of course, it is love to her work, adherence to her life principles. Lidia Ivanovna appreciated business trips, exchanging opinions with colleagues at the conferences and symposiums, communicating with students during lectures.

She was interested not only in new scientific publications, but also in the news of literature and arts, the events in the Republic and in the World. She was always full of new ideas and plans. Her departure from life is a deep and irreparable loss to Belarusian Anthropology.

O. Marfina

O. Goncharova

\section{PAPERS BY L.I., PUBLISHED IN ESTONIA}

Tegako L.I. (1982). To the problem of time changeability of anthropological signs on the territory of BSSR. Problems of Physical Anthropology. Tartu, 58-60 (in Russian).

Tegako L.I. (1985). Complex approaches to study dental traits in BSSR population. Problems of Modern Anthropology. Tartu, 87-89 (in Russian).

Tegako L.I. (1988). Analysis of age and sex changeability of dermatoglyphic signs in population. Modern Anthropology to Medicine and National Economy. Tallinn, 61-63 (in Russian).

Tegako L.I., Salivon I.I., Marfina O.V., Polina N.I. (1988). To the problem of anthropological groups in the urban population of BSSR. Actual Problems of Anthropology. Tartu, 114-126 (in Russian).

Tegako L., Marfina O. (2008). Dynamic observation of physical development indices of schoolchildren in the Republic of Belarus. Papers on Anthropology, XVII, 272-281.

\section{Address for correspondence:}

Olga Marfina

Department of Anthropology and Ecology, Institute of History National Academy of Sciences of Belarus (NAS)Minsk, Belarus

Akademicheskaya 1

Minsj, 220072, BELARUS

E-mail: belantrop@tut.by 